\begin{tabular}{|c|c|}
\hline UDC 005:658.713: & DOI: https://doi.org/10.31617/zt.knute.2021(119)09 \\
\hline JEL Classification M21 & \\
\hline $\begin{array}{r}\text { BLAKYTA Hanna } \\
\text { E-mail: g.blakyta@knute.edu.ua } \\
\text { ORCID ID: 0000-0001-7843-7120 }\end{array}$ & $\begin{array}{l}\text { DSc (Economics), Professor, Head of the Department } \\
\text { of Economics and Business Finance of Kyiv National } \\
\text { University of Trade and Economics } \\
\text { 19, Kioto Str., 02156, Kyiv, Ukraine }\end{array}$ \\
\hline $\begin{array}{r}\text { BARABASH Nataliia } \\
\text { E-mail:n.barabash@knute.edu.ua } \\
\text { ORCID ID:0000-0002-1011-527X }\end{array}$ & $\begin{array}{l}\text { PhD (Economics), Associate Professor, Professor } \\
\text { at the Department of Economics and Business Finance } \\
\text { of Kyiv National University of Trade and Economics } \\
\text { 19, Kioto Str., 02156, Kyiv, Ukraine }\end{array}$ \\
\hline $\begin{array}{r}\text { PASHKUDA Tetiana } \\
\text { E-mail: t.pashkuda@knute.edu.ua } \\
\text { ORCID ID: 0000-0002-0490-9321 }\end{array}$ & $\begin{array}{l}\text { PhD (Economics), Senior Lecturer } \\
\text { at the Department of Economics and Business Finance } \\
\text { of Kyiv National University of Trade and Economics } \\
\text { 19, Kioto Str., 02156, Kyiv, Ukraine }\end{array}$ \\
\hline
\end{tabular}

\title{
DIGITAL MANAGEMENT OF LEASING TRANSACTIONS OF ENTERPRISES*
}

The article substantiates the need to manage leasing transactions of enterprises with the use of innovative IT technologies. The role and place of digitalization of management have been studied. The classification of leasing payments, methodical support of the analysis of leasing transactions has been presented. innovations.

Keywords: enterprise, economic activity, digital management, leasing,

Background. Simultaneously with the deepening of the processes of digital globalization, about $25 \%$ of the world economy has moved to the introduction of digitalization technologies that allow the state, business, and society to function more efficiently.

Developed countries, having completed industrialization, are successfully digitizing the economy, rapidly developing innovative technologies dominated by artificial intelligence, automation, and digital platforms [1, p. 62].

The development of domestic society, the creation of new and modernization of existing technologies necessitate changes in the «usual» activities of economic entities. The XXI century has significantly actualized the field of research for scientists and practitioners due to the rapid development and spread of information and communication and digital technologies. The above technologies are the foundation of the digital

* The article was prepared as part of the research work «Digital Transformation of Trade, Economic and Tourist Systems of Ukraine» (state registration number 0121U112231).

(C) Blakyta H., Barabash N., Pashkuda T., 2021 
economy, the interest in the formation and development of which is growing every year not only in the world but also in the domestic community. Confirmation of this opinion at the national level is the Concept of development of the digital economy and society of Ukraine for 2018-2020 approved by the Cabinet of Ministers of Ukraine [2].

Given the constant growth in the number of businesses in the market, as evidenced by the State Statistics Service [3] (Figure 1), companies urgently need to find new ways to increase their competitive position and capture larger segments.

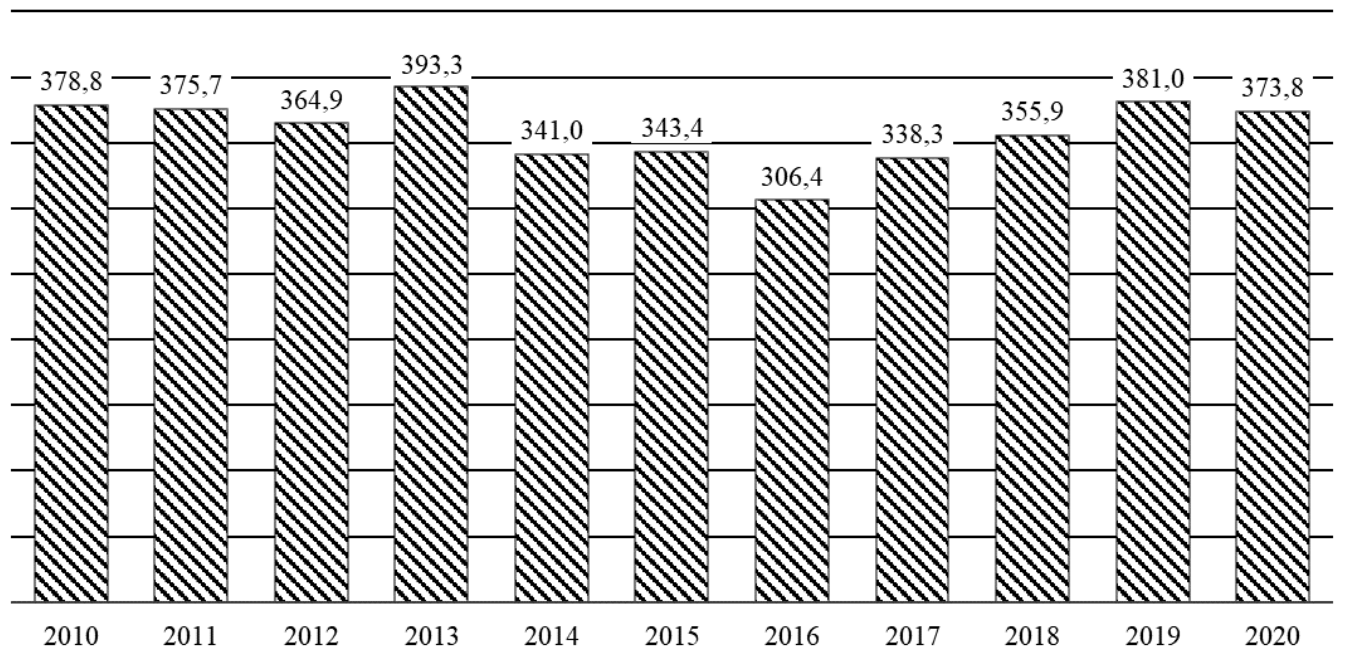

Figure 1. Dynamics of the number of business entities in Ukraine during 2010-2020

Source: developed on the basis of data from the State Statistics Service of Ukraine [3].

The need to implement information and communication capabilities and benefits of modern IT-technologies, the need to gain a leading position and strengthen the competitive position require the management of prudent policies for digitalization, stimulating investment to promote digital technologies, based on scientific theories and concepts of economic development.

Analysis of recent research and publications. A large number of scientific works of such scientists as Rudenko M. V. [1], Gerasymovych A. M. [4], Shevchuk I. B., Deputy B. Ya., O. Ye. Tarasenko [5], M. M. Dudchenko, Pavlenko T. V. [6], S. V. Kalabukhova [7], Tulchynska S. O., Korzun L. S [8], O. A. Levchenko [9], Ya. V. Onyshchuk [10], K. Y. Pugachevskyi, K. S. Pugachevskaya [11], and many others are devoted to diagnostics of separate questions of management of leasing transactions of the enterprises, including strengthening processes of digitalization of the economy. Despite their thoroughness, comprehensive researches that would contain a detailed study of organizational and methodological support on this topic are missing. This necessitates the study of a number of issues.

The aim of the study is to develop methodological approaches to the analysis of taxation of trade enterprises.

Materials and methods. The information base of the article is presented by scientific works of domestic and foreign scientists [1-2; 4-11]. 
The research is based on scientific methods, among which it is expedient to distinguish: analysis and synthesis, comparison, idealization, and abstraction, as well as systematization and generalization - during the formulation of conclusions as a result of the study.

Results. Digitalization of management processes is closely related to the innovative activities of enterprises. According to the State Statistics Service of Ukraine [3], simultaneously with the growth of the total number of business entities, the share of innovatively active enterprises is growing every year (Figure 2).

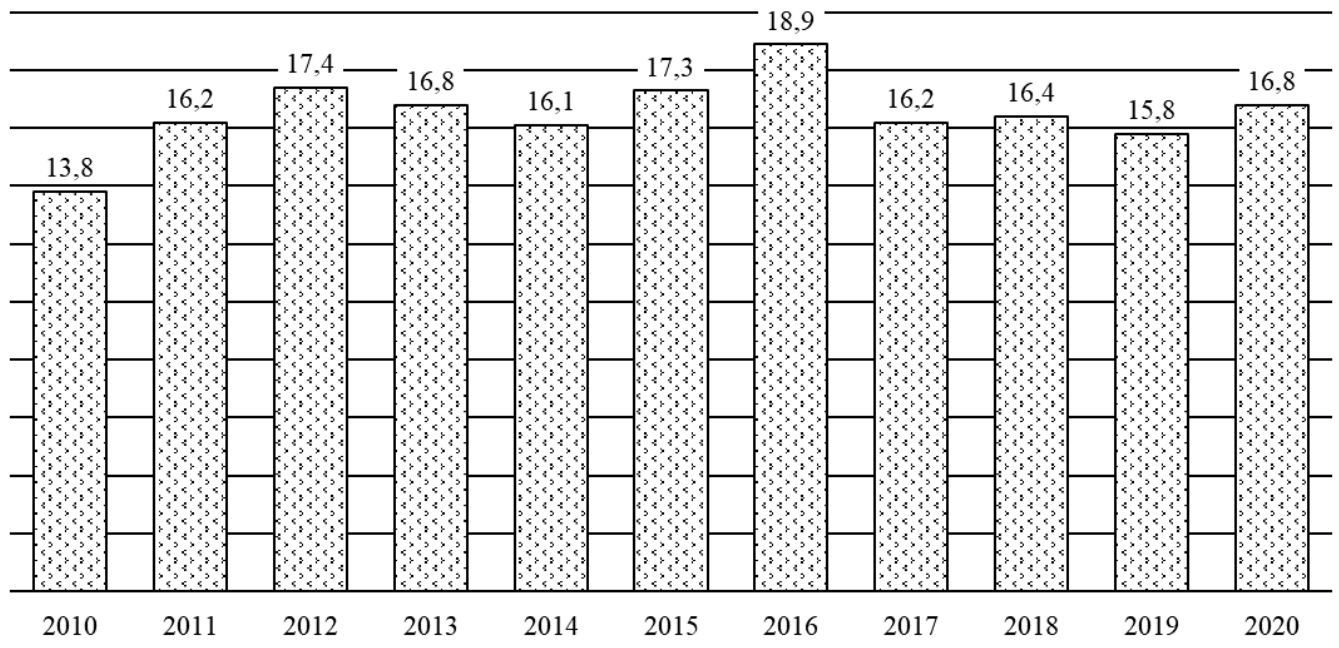

Figure 2. Dynamics of the share of innovatively active enterprises in the total number of enterprises in Ukraine during 2010-2020

Source: developed on the basis of data from the State Statistics Service of Ukraine [3].

At the same time, the cost of innovation is growing (Figure 3). During 2010-2020, there was a sharp decline in 2014 to UAH 7695.9 million, an increase in expenditures in 2016 to UAH 23229.5 million. Such instability is primarily due to the intensification of the crisis in the country and reflects the escalation of the war in the East, the economic and political crisis, etc.

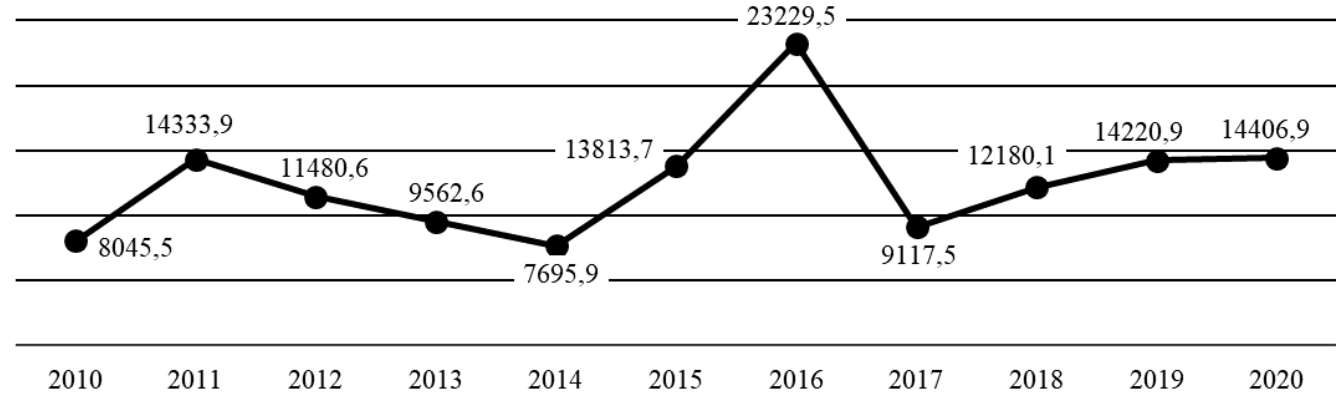

Figure 3. Dynamics of the volume of expenditures on innovations of enterprises in Ukraine during 2010-2020, UAH million

Source: developed on the basis of data from the State Statistics Service of Ukraine [3]. 
Digitization makes it possible to process large amounts of information, process large databases, and speed up operational processes. Digitalization acquires special relevance during the management of leasing transactions of enterprises.

The introduction of innovations, advanced technologies, and new technology through leasing is a special area of use and movement of capital in the system of expanded reproduction. This economic process differs from traditional processes of production and sale of products in the way that it is directly related to the creation of new and replacement and renewal of existing fixed assets.

Leasing differs from the traditional category of investment. The latter in a generalized form expresses the process of investing in production, construction, technical development, and other activities, and therefore does not fully reflect the specifics of innovative leasing activities. In these conditions, there is a need to develop a methodology for analysis and evaluation of leasing transactions, which allows choosing, evaluate and economically justifying solutions that ensure the effectiveness of their implementation.

The following basic indicators are used for the analysis of leasing transactions:

- the level of absolute efficiency, which is determined by the ratio of operating income from leasing to the value of leased assets;

- the costs of leasing and the coefficient of the comparative efficiency of alternative investment options (payback period of additional funds);

- total profit and level of profitability of leasing transactions;

- payback period of leased equipment or capital investments.

Based on the characteristics of the leasing process and taking into account its innovation, the most adequate indicator is the rate of return and, as a consequence, indicators of profitability and cost-effectiveness.

Assessing the actual effectiveness of innovative investment through leasing, as well as choosing and economically justifying design and planning decisions, it is advisable to use general indicators of the absolute and relative growth of net profit and the level of profitability of leasing transactions [7].

The choice of a specific option of leasing transactions is on a multivariate and multi-criteria basis.

An alternative basis for choosing the effectiveness of leasing activities involves linking the future outcome of this operation with the main purpose of its implementation by the criteria: increase of net profit, minimum payback period, maximum profitability, cost reduction, or social programs at different levels.

Analyzing the effectiveness of the leasing transaction, it is necessary to compare the benefits of the lessor and the lessee so that the resulting vector of interests of the parties to the lease transaction was the most favorable for all parties. 
This is obvious because there is a direct connection between this phenomenon: the more profitable leasing operation for the lessee, the greater the interest of the business sector in this type of lending, and increasing demand stimulates supply, and vice versa, the greater the supply of leasing services in the market, the greater interest from potential lessees.

When analyzing the effectiveness of leasing, the system of calculating the number of payments for this type of loan deserves the most attention.

For the most complete idea of the mechanism of payment for leasing transactions, it is necessary to distinguish their classification groups, structure, and method of accrual of lease payments. Classification characteristics of types of payments for leasing transactions are given in Figure 4.

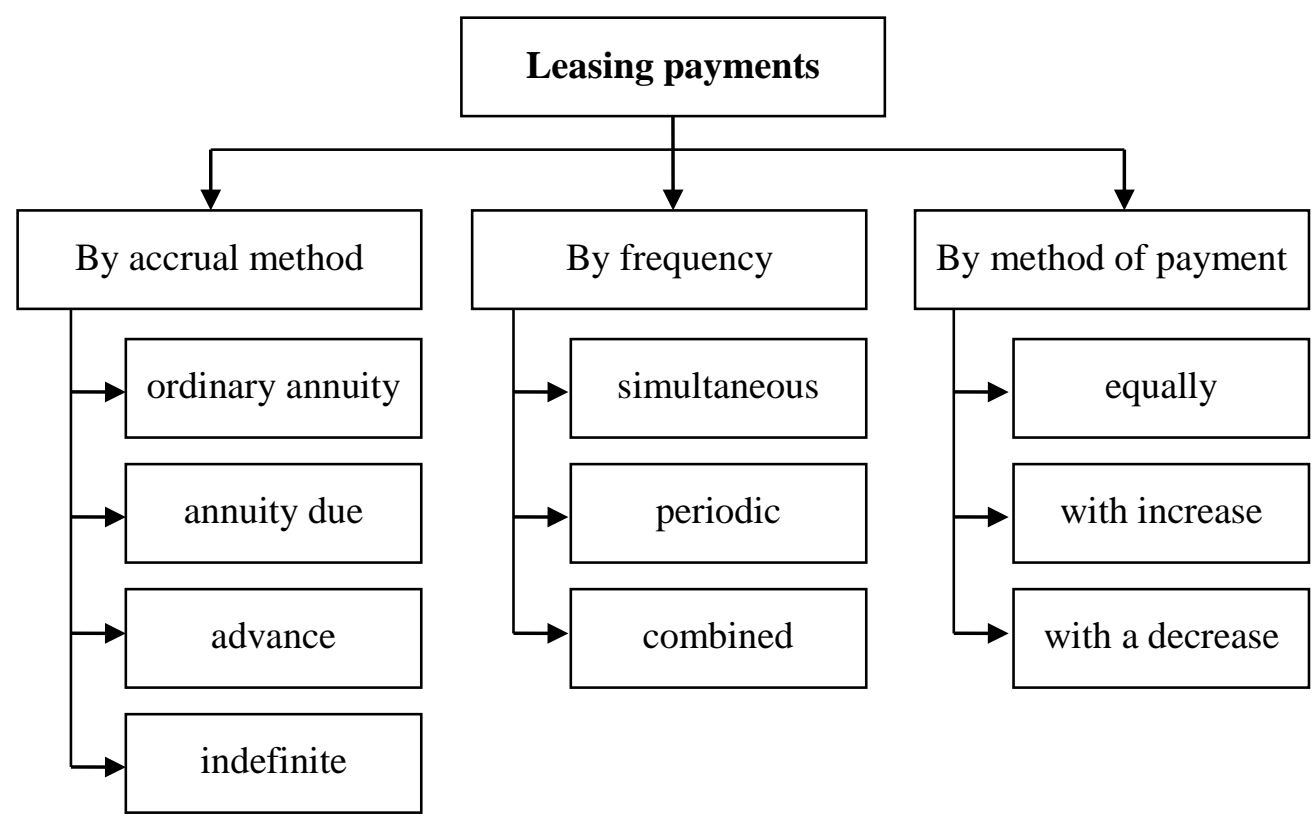

Figure 4. Classification of types of payments for leasing transactions

Source: developed on the basis of data.

Depending on the accrual method lease payments are distinguished as:

- Ordinary annuity, including depreciation of the cost of leased equipment, the amount of the so-called commission to the lessor, which includes the percentage of services per transaction that are paid at the end of each period;

- Annuity due has a structure similar to an ordinary annuity, but is made at the beginning of each period;

- Advance (deposit) payments take place in cases when the lessee of the property first provides the lessor with an advance at the time of signing the agreement in the prescribed amount, and then, after signing the act of commissioning, pays periodic installments for the total amount of lease payment (minus the advance);

- Indefinite payments, the analysis of which is carried out by changing the percentage set in the agreement, determined on a certain basis. 
As a basis, by mutual consent, can be taken: the volume of sales of products manufactured on leased equipment; the amount of profit received from the sale, or other parameters that may be changed during the lease agreement.

According to the frequency of payments, there are:

- periodic payments (annual, quarterly, monthly), paid according to the schedule agreed by the parties, which is attached to the leasing agreement;

- one-time payments made if the agreement provides for the payment of an advance to the lessor;

- combined payments, which are a combination of periodic payments with an advance payment in the case when the latter is provided for in the lease agreement.

Taking into account the financial condition and payment capabilities the following payments are distinguished:

- equal;

- increasing (used mainly by lessees with an unstable financial condition, when at the initial stage of leasing the user is more convenient to make a lease payment in small installments, and then in process of development of the equipment and increase of rates of release of products made on it, to increase them);

- decreasing (accelerated payments used by lessees with a stable financial position, when in the initial period of the lease the user prefers to repay most of its debts to the lessor).

Payments under the lease agreement consist of the value of the leased asset in the amount of depreciation, fees for resources used by the lessor, taking into account the required reserve funds, payments for additional services of the lessor, as well as based on the average level of cost-effectiveness and profitability of the lessor for other credit operations.

Additional financial services provided by the lessor may be the insurance of the leased object against a possible insured event related to partial or complete loss of the object caused by emergencies, careless use, factory defects, or other reasons. As a rule, the amount of insurance premium is 1-2\% per year of the value of the leased object.

Depreciation on the used leased asset may be accrued on a straightline basis depending on its carrying amount, useful life, and established depreciation rates under the tax method.

Various methodological approaches are used to analyze the validity of leasing payments. The most common is a technique based on the theory of term annuity.

These calculations are based on a compound interest model (or accrual formula):

$$
F V=P V(1+r) t
$$

where: $F V$ - the future value of the current object of leasing (or the amount of the loan and interest returned to the lessor), thousand UAH; 
$P V$ - the present amount of cash that determines the value of the leased object, thousand UAH;

$t$ - term of the lease agreement, years;

$r$ - the effective annual interest rate on the loan, the ratio.

The formula does not take into account the specifics of leasing transactions used by the lessor, based on the theory of rent payments. Determining the frequency and amount of payments, as well as the interest on the lease is carried out in two ways: one, the percentage of the lease is set based on the frequency of payment by the lessee of lease payments, which is determined based on the feasibility study of the lease project, in accordance with the business plan of the lessee and the interests of the lessor. In this case, the more often payments are made, the lower the percentage, other things being equal.

Alternatively, the lease interest is determined based on the specific leasing rate that best satisfies the lessor. Based on its level of costeffectiveness and profitability, the frequency of payments is set, which most accurately provides a given interest rate.

This conclusion is based on the theory of effective annual interest rate, which is defined as:

$$
i=\left(1+\frac{j}{m}\right)^{m}-1
$$

where: $i$ - effective annual interest rate;

$j$ - nominal annual interest rate;

$m$ - the number of periods of rent payments per year.

The economic significance of this indicator is that the greater the number of periods of payment of rent per year, the higher its value, and therefore the more expensive the lease for the lessee. This is because the effective interest rate does not take into account the reinvestment of lease payments, as if the lessee did not pay rent payments, but used them for domestic purposes.

This condition is best met by the formula for calculating rent payments, used in the theory of term annuity, which is based on the assessment of cash flows and the calculation of the nominal interest rate:

$$
j=m(\sqrt[m]{1+j-1})
$$

Complementing the theory with the specifics of the tasks of leasing operations, which reflect the interrelated effect on the number of rent payments of all terms of the lease agreement, namely: the amount and term of the contract, the level of leasing interest, and frequency of payments, we obtain the formula of rent payments which looks like this:

$$
P M T=P V \frac{j / m}{1-(1+/ m)^{-t m}}
$$

where: $P M T$ - the number of rent payments thousand UAH. 
The problem in which it is necessary to calculate the number of lease payments paid by the recipient at the beginning of each period is solved using the formula for calculating annuity due:

$$
P M T=P V \frac{j / m}{(1+j / m)\left[1-(1+j / m)^{-t m}\right]}
$$

A special case of this variant of rent payments of the annuity due is advance payment by the lessee of a certain part of the leased object in the amount established by agreement of the parties to the leasing transaction.

Adding in the first (ordinary annuity) and in the second (annuity due) case the value of PMT rent payments, we find the total amount of lease payments made by the lessee $(F V)$ and from the formula we determine the percentage at which the lessee actually, but without taking into account the time factor, received a lease loan $(r)$ :

$$
r=\sqrt[n]{\frac{F V}{P V}}-1
$$

The economic significance of this indicator is that the real interest rate on the leasing transaction $(r)$ will be much lower than the bank interest rate on the loan $(i)$.

It should be noted that the reinvestment of lease payments is appropriate for the lessor only at a rate equal to or exceeding the bank interest on the loan. Otherwise, the cost-effectiveness of the leasing transaction (excluding tax benefits for the leasing transaction) will be lower.

The same statement is true for the lessee in the sense that repayment of the lease loan by payment of rent payments is effective only if the number of funds from the production cycle to pay the leased payments can not be used (invested) by the lessee at a rate exceeding bank interest (i).

Conclusion. Analysis of leasing transactions of the enterprise creates a scientific basis for management decisions and meets the information needs of users of financial statements, and is analytical support for management functions, including planning, forecasting, monitoring the implementation of plans, determining deviations from actual targets, regulation. It is with the help of the analysis of leasing operations that one can make timely adjustments to the planned tasks and adjust the situation and indicators

The use of digital technologies in management helps to increase the efficiency of management and strengthen the financial well-being of the enterprise as a whole. It is due to the digitalization of activities, including management, there is an opportunity to process large amounts of information, process large databases, and speed up operational processes, which is extremely important when managing leasing transactions of enterprises. 


\section{REFERENCES}

1. Rudenko M.V. (2018) Digitalization of the economy: new opportunities and prospects. Economics, 2018, 61-65 [in Ukrainian].

2. On approval of the Concept of development of the digital economy and society of Ukraine for 2018-2020 and approval of the action plan for its implementation. Order of the Cabinet of Ministers of January 17, 2018 № 67-r.: URL: http://zakon.rada.gov.ua/laws/show/67-2018-\% D1\% 80.

3. State Statistics Service of Ukraine : URL: http://www.ukrstat.gov.ua.

4. Gerasimovich A.M., Morozova-Gerasimovich N.A. (2009) Leasing operations: essence, mechanism of carrying out, taxation, accounting, analysis. Finance, Accounting and Auditing, 13, 184-197 [in Ukrainian].

5. Shevchuk I.B., Deputy B.Ya., Tarasenko O.E. (2019) Digitization and its impact on the economy of Ukraine: advantages, challenges, threats and risks. Black Sea Economic Studies, 47-2, 173-177 [in Ukrainian].

6. Duchenko M.M,. Pavlenko T.V. (2019) Status and prospects of development of the leasing industry in Ukraine. Efficient economy, 1, 59-64 [in Ukrainian].

7. Kalabukhova S.V. (2015) Analysis of the efficiency of leasing operations. Problems of theory and methodology of accounting, control and analysis, 3 (30), 159-165 [in Ukrainian].

8. Tulchinskaya S.O., Korzun L.S. (2020) Digitalization as a means of transformation of Ukraine's economy. Modern problems of economy and entrepreneurship, 25, 52-59 [in Ukrainian].

9. Levchenko O.A. (2017) Theoretical fundamentals of leasing operations as an effective means of recovery of the national economy. Financial space, 1 (25), 58-64 [in Ukrainian].

10. Onishchuk Ya.V. (2005) Development of leasing in Ukraine. Finance of Ukraine, 7, 106-113 [in Ukrainian].

11. Pugachevskyi K.Y., Pugachevskaya K.S. (2018) Digitalization of the economy as a factor of increasing the country's competitiveness. Market infrastructure, 25, 39-45 [in Ukrainian].

The article submitted to editor's office on 12.11.2021.

\section{Блакита Г., Барабаш Н., Пашкуда Т. Диджитал-управління лізин- говими операціями підприємств. \\ Постановка проблеми. Одночасно з поглибленням прочесів ичифрової} глобалізачії близько 25\% світової економіки перейшло до впровадження технологій циирровізації, щуо дають змогу державі, бізнесу та суспільству функиіонувати ефективніше. Необхідність реалізації інформаційнокомунікаційних можливостей $i$ переваг сучасних IT-технологій, потреба в набутті провідних позицій $i$ зміцнення конкурентного положення вимагають від керівництва зваженої політики щуодо диджиталізації, стимулювання інвестииійної діяльності з метою просування ицифрових технологій, спираючись на наукове підгрунтя теорій $і$ концепцій економічного розвитку.

Завдяки диджситалізаиії з'являсться можливість обробки масштабних обягів інформації, опрацюювання великих баз даних і пришвидшення опера- 
ціийних процесів. Особливої актуальності диджиталізація набуває під час управління лізинговими операчіями підприємств.

Мета дослідження полягає у розробиі методичних підходів щуодо здійснення диджитал-управління лізинговими операчіями підприємств.

Матеріали та методи. Інформаційна база статті представлена науковими прачями вітчизняних та закордонних учених. Основою дослідження $\epsilon$ наукові методи, зокрема: аналіз $i$ синтез, порівняння, ідеалізація та абстрагування, а також систематизація та узагальнення задля формулювання висновків у результаті проведеного дослідження.

Результати дослідження. Впровадження інновацій, прогресивних технологій і нової техніки через лізинг є особливою сферою використання й руху капіталу в системі розширеного відтворення. Цей економічний прочес відрізняється від традииійних прочесів виробництва та продажу продукиї тим, щуо він безпосередньо пов'язаний зі створенням нових $i$ заміною та оновленням наявних основних засобів. Лізинг відрізняється від традииійної категорії інвестииії. За циих умов виникає потреба розробки методики аналізу й очінки лізингових операцій, щуо дає можливість вибирати, оиінювати і економічно обтрунтовувати рішення, які забезпечують ефективність їхнього впровадження.

Висновки. Застосування диджитал-технологій в управлінні сприяє підвищенню ефективності менеджменту та зміиненню фінансового благополуччя підприємства загалом, зокрема й управління, з'являється можливість обробки масштабних обсягів інформащії, опрацювання великих баз даних і пришвидмення операційних процесів, щзо надзвичайно важливо під час управління лізинговими операчіями підприємств.

Ключові слова: підприємство, господарська діяльність, диджиталуправління, лізинг, інновації. 